\title{
Article
}

\section{Type I Interferon Promotes Antitumor T Cell Response in CRPC by Regulating MDSC}

\author{
Lilv Fan ${ }^{1}$, Guiliang Xu ${ }^{1}$, Jingjing Cao ${ }^{1}$, Min Li ${ }^{1}$, Huihui Zhang ${ }^{1}$, Fanlin $\mathrm{Li}^{1}{ }^{1}$, Xinyue $\mathrm{Qi}^{1}{ }^{1}$, Xiaoqing Zhang ${ }^{1}$, \\ Zeyu Li ${ }^{1}$, Ping Han ${ }^{1}$ and Xuanming Yang ${ }^{1,2, *}$
}

1 Sheng Yushou Center of Cell Biology and Immunology, School of Life Sciences and Biotechnology, Shanghai Jiao Tong University, Shanghai 200240, China; fanlilv@sjtu.edu.cn (L.F.); asdxgl@163.com (G.X.); jjcao@sjtu.edu.cn (J.C.); limin_1216@sjtu.edu.cn (M.L.); ninxia0@sjtu.edu.cn (H.Z.); lifanlin@sjtu.edu.cn (F.L.); xinyueqi@sjtu.edu.cn (X.Q.); zxq0318@sjtu.edu.cn (X.Z.); davidking2007@sina.com (Z.L.); esterhanping@sjtu.edu.cn (P.H.)

2 Joint International Research Laboratory of Metabolic \& Developmental Sciences, Shanghai Jiao Tong University, Shanghai 200240, China

* Correspondence: xuanmingyang@sjtu.edu.cn; Tel.: +86-21-3420-4065

check for updates

Citation: Fan, L.; Xu, G.; Cao, J.; Li, M.; Zhang, H.; Li, F.; Qi, X.; Zhang, X.; Li, Z.; Han, P.; et al. Type I Interferon Promotes Antitumor T Cell Response in CRPC by Regulating MDSC. Cancers 2021, 13, 5574. https:/ / doi.org/10.3390/cancers13215574

Academic Editor: Samuel C. Mok

Received: 23 August 2021

Accepted: 3 November 2021

Published: 8 November 2021

Publisher's Note: MDPI stays neutral with regard to jurisdictional claims in published maps and institutional affiliations.

Copyright: (c) 2021 by the authors. Licensee MDPI, Basel, Switzerland. This article is an open access article distributed under the terms and conditions of the Creative Commons Attribution (CC BY) license (https:// creativecommons.org/licenses/by/ $4.0 /)$.
Simple Summary: Despite initial tumor regression following androgen blockade treatment, relapse of castration-resistant prostate cancer (CRPC) eventually occurs in most patients. Immunotherapy aims to activate the host immune system to fight against cancer and has achieved significant therapeutic effects in various solid tumors. The purpose of our research was to investigate the mechanisms underlying the immune response during CRPC development and to screen effective immunotherapies against CRPC. We found that interferon- $\alpha$ (IFN $\alpha$ ) directly inhibited the progression of CRPC, reduced the accumulation of the immune suppressive granulocytic myeloid-derived suppressor cells (G-MDSCs) in the tumor microenvironment (TME), and impaired the inhibitory function of G-MDSCs on T cell activation. This research provides a potential strategy for the clinical treatment of CRPC.

Abstract: Background: Metastatic castration-resistant prostate cancer (CRPC) is the leading cause of death among prostate cancer patients. Here, our aim was to ascertain the immune regulatory mechanisms involved in CRPC development and identify potential immunotherapies against CRPC. Methods: A CRPC model was established using Myc-CaP cells in immune-competent FVB mice following castration. The immune cell profile of the tumor microenvironment (TME) was analyzed during CRPC development. Different immunotherapies were screened in the CRPC tumor model, and their efficacies and underlying mechanisms were investigated in vitro and in vivo. Results: During CRPC development, the proportion of granulocytic myeloid-derived suppressor cells (GMDSCs) in the TME increased. Among the immunotherapies tested, IFN $\alpha$ was more effective than anti-PD-L1, anti-CTLA-4, anti-4-1BB, IL-2, and IL-9 in reducing Myc-CaP CRPC tumor growth. IFN $\alpha$ reduced the number of G-MDSCs both in vitro during differentiation and in vivo in CRPC mice. Furthermore, IFN $\alpha$ reduced the suppressive function of G-MDSCs on T cell proliferation and activation. Conclusion: G-MDSCs are crucial to effective immunotherapy against CRPC. Treatment with IFN $\alpha$ presents a promising therapeutic strategy against CRPC. Besides the direct inhibition of tumor growth and the promotion of T cell priming, IFN $\alpha$ reduces the number and the suppressive function of G-MDSCs and restores T cell activation.

Keywords: IFN $\alpha$; prostate cancer; G-MDSC; immunotherapy

\section{Introduction}

Prostate cancer is the second most commonly diagnosed cancer among men worldwide [1]. The incidence of prostate cancer is related to factors such as age, genetics, and ethnicity [2,3]. As the tumor grows, it spreads to tissues such as bone and lymph nodes. 
Surgery and radiotherapy, the most common treatment strategies for prostate cancer, have side effects, such as incontinence and sexual dysfunction [4]. The growth and development of prostate cancer were considered to be associated with androgens [5]. Consequently, androgen deprivation has been widely used clinically as an effective treatment strategy for prostate cancer. In addition to surgical methods, certain chemical castration drugs, such as abiraterone acetate, an inhibitor of androgen synthesis, and enzalutamide, an inhibitor of androgen receptors, have also been used [6,7]. However, about $20-40 \%$ of metastatic CRPC patients show no response to the drugs used for the treatment of castration-resistant tumors, eventually resulting in low drug efficacy among all men [8].

Compared to conventional therapies (chemotherapy and surgery), immune therapies, such as immune checkpoint inhibitors, cytokines, cellular immunotherapy, etc., have been proven to possess improved clinical therapeutic effects against many tumors. Interferons (IFNs) are a family of cytokines that directly act on tumor cells or indirectly activate the immune response to resist invasion by cancer cells [9]. IFN $\alpha$ belongs to the type I IFN family. Its receptor is composed of two subunits: IFNAR1 and IFNAR2 [10]. Most cells in the body secrete and respond to IFN $\alpha$. It plays an important role in the immune response against viruses and tumors. IFN $\alpha$, through the JAK-STAT signaling pathway, induces the translocation of STAT1/2 heterodimers or STAT1 homodimers into the nucleus and drives the expression of IFN-related genes [11,12]. It regulates numerous genes associated with tumor proliferation, survival, and migration [13]. In vitro, IFN $\alpha$ upregulates p21 in prostate cancer cells and slows down the cell cycle [14]. In addition to its direct effects on tumors, IFN $\alpha$ also regulates the antitumor immune response of almost all types of immune cells. It improves the generation and survival of tumor-specific $\mathrm{T}$ cells [15], enhances the cytotoxicity of natural killer (NK) cells to tumors [16], increases survival and promotes the antibody response of B cells [17], induces the maturation of dendritic cells (DCs) and enhances their ability to cross-present tumor-associated antigens to CD8 ${ }^{+} \mathrm{T}$ cells [18,19], negatively regulates the proliferation of regulatory $\mathrm{T}$ cells (Tregs) [20], and induces the antigen-presenting cell (APC)-mediated expression of IL-15, which is critical for the proliferation and maintenance of lymphocytes [21].

There are multiple immune suppressive cell subtypes in the solid tumor microenvironment (TME). Treg, myeloid-derived suppressor cells (MDSCs), and tumor-associated macrophages (TAMs) in the TME inhibit the functions of immune effector cells such as T cells and NK cells $[22,23]$. MDSCs are derived from the bone marrow. In cancer patients, the tumor cells secrete cytokines, such as GM-CSF, G-CSF, and IL-6 [24], and result in the hematopoietic stem cells in the bone marrow abnormally developing into MDSCs. The tumor cells also secrete CCLs and CXCLs and other chemokines, then recruit MDSCs to the TME to exert immunosuppressive functions [25]. MDSCs reduce the level of L-arginine, which is required for the proliferation of T cells in the TME, through Arg1, and produce NO, ROS, and peroxynitrite (PNT), which inhibit T cells from entering the TME [26]. They also produce immunosuppressive cytokines, such as IL-10 and TGF- $\beta$, which induce the generation of Tregs [27,28]. MDSCs are divided into two subgroups: monocytic MDSCs (M-MDSCs) and granulocytic MDSCs (G-MDSCs). Although both M-MDSCs and G-MDSCs possess immunosuppressive functions, the ratio of G-MDSCs/M-MDSCs of different tumors is quite different [29].

In this study, we detected the changes in the TME during CRPC development. We found that the proportion of G-MDSCs increased significantly. We also tested the effectiveness of several immune checkpoint inhibitors and cytokines for the treatment of CRPC and found that IFN $\alpha$ treatment inhibited tumor growth and reduced the accumulation of G-MDSCs in the TME. This antitumor effect of IFN $\alpha$ depended on the CD8 ${ }^{+} \mathrm{T}$ cells. Furthermore, both in vivo and in vitro, IFN $\alpha$ significantly reduced the number of G-MDSCs in the bone marrow. In vitro, it significantly decreased the immunosuppressive function of G-MDSCs on T cells by upregulating the expression of immune-promoting molecules. This work provides a potential strategy for the treatment of CRPC. 


\section{Materials and Methods}

\subsection{Mice}

FVB mice were purchased from Shanghai Lingchang Biotechnology Co., Ltd. Ifnar1 $1^{-/-}$mice were kindly provided by Dr. Anita Chong from the University of Chicago. Ifnar $1^{-/-}$FVB mice were generated by crossing the Ifnar ${ }^{-/}-\mathrm{C} 57 \mathrm{BL} / 6$ mice and the FVB mice for 6 generations.

\subsection{Cell Lines and Reagents}

$\mathrm{Myc}-\mathrm{CaP}$ is a prostate cancer cell line derived from the spontaneous prostate tumor in mice [30]. Myc-CaP cells were cultured in Dulbecco's Modified Eagle Medium (DMEM) supplemented with 10\% heat-inactivated fetal bovine serum (FBS) (Gibco, Paisley, UK), 100 units/mL penicillin, $100 \mu \mathrm{g} / \mathrm{mL}$ streptomycin, $2 \mathrm{mM}$ L-glutamine, and $55 \mu \mathrm{M} \beta$ mercaptoethanol. Cells were cultured in an incubator at $37{ }^{\circ} \mathrm{C}$ with $5 \% \mathrm{CO}_{2}$.

\subsection{Myc-CaP Treatment In Vitro}

A total of $3 \times 10^{4}$ Myc-CaP cells were seeded in 24 well plates with DMEM complete culture medium supplemented with PBS or IFN $\alpha 4$ (50 or $200 \mathrm{ng} / \mathrm{mL}$ ). After $48 \mathrm{~h}$, the cells were digested with trypsin, and the number of cells was counted using a hemocytometer.

\subsection{MDSCs Differentiation from Bone Morrow Cells}

Femurs and tibias were obtained from male FVB mice, and the bone marrow cavities were flushed with PBS using an insulin syringe. ACK (Ammonium-Chloride-Potassium) lysis buffer (BD Biosciences, San Jose, CA, USA) was used to lyse the red blood cells in all samples. Bone marrow cells were cultured in Petri dishes containing RPMI-1640 complete culture medium supplemented with $20 \mathrm{ng} / \mathrm{mL}$ GM-CSF (Sinobiological Catalog No: 51048-MNAH, Beijing, China) and induced for 4 days by treating with PBS or IFN $\alpha 4$ (20 ng/mL or $100 \mathrm{ng} / \mathrm{mL}$ ), to generate bone marrow-derived MDSCs (BM-MDSCs). On day 4 , the proportion of G-MDSCs was detected by flow cytometry, and the cell number was obtained using a hemocytometer.

\subsection{Isolation of G-MDSCs}

Bone marrow cells were induced for 4 days. The single-cell suspension was incubated with 2.4G2 (antibodies recognizing CD16 and CD32) for 10 min to block non-specific Fcmediated binding. The BM-MDSCs were magnetically labeled with anti-Ly-6G-Biotin (1A8) (Biolegend, San Diego, CA, USA) and Streptavidin Nanobeads (Biolegend). Subsequently, they were separated on a magnetic rack to obtain G-MDSCs.

\subsection{T Cell Inhibition by G-MDSCs}

Mouse spleens were ground and passed through a $70 \mu \mathrm{m}$ cell strainer. Red blood cells were lysed using ACK lysis buffer and isolated using the MojoSort ${ }^{\mathrm{TM}}$ Mouse CD3 T Cell Isolation Kit (BioLegend), according to the manufacturer's instructions. The purified $\mathrm{T}$ cell suspension was incubated in the dark with $5 \mu \mathrm{M}$ carboxyfluorescein succinimidyl ester (CSFE) (Selleck, Boston, MA, USA) for $7 \mathrm{~min}$ and washed twice with RPMI-1640 complete culture medium to remove the unbound CFSE. Subsequently, they were cocultured with Ly6G+ BM-MDSCs in the ratio of 1:1 and 3:1 in 96-well plates with RPMI-1640 complete culture medium (10\% heat-inactivated FBS, 100 units $/ \mathrm{mL}$ penicillin, $100 \mu \mathrm{g} / \mathrm{mL}$ streptomycin, $2 \mathrm{mM}$ L-glutamine, and $55 \mu \mathrm{M} \beta$-mercaptoethanol). Plate-bound anti-CD3 $(0.5 \mu \mathrm{g} / \mathrm{mL})$ and anti-CD28 $(1 \mu \mathrm{g} / \mathrm{mL})$ antibodies were used to stimulate the T cells in the culture. Forty-eight hours after activation, the cells and supernatants were collected for flow cytometry and cytometric bead array (CBA) analyses.

\subsection{Isolation of Single Cells from Tumors}

Mouse tumor tissues were sliced to pieces using surgical scissors and digested in tumor dissociation buffer (RPMI-1640 with $50 \mu \mathrm{g} / \mathrm{mL}$ Liberase TL (Roche) and $200 \mu \mathrm{g} / \mathrm{mL}$ 
DNase I (Sigma, St Louis, MO, USA)). The tumor tissues were ground and passed through a $70 \mu \mathrm{m}$ cell strainer. The single cells obtained were re-suspended in staining buffer $(1 \times$ PBS with $1 \%$ FBS $)$.

\subsection{Flow Cytometry Analysis}

Single-cell suspensions of cells were incubated with $2.4 \mathrm{G} 2$ for $10 \mathrm{~min}$. Blocked samples were subsequently stained with fluorescently labeled monoclonal antibodies and a fluorescent intercalator. The anti-mouse CD45-APC / Cyanine7 (30-F11 Catalog No: 103116), anti-mouse Ly-6C-FITC (HK1.4 Catalog No: 128006), anti-mouse CD11c-PE (N418 Catalog No: 117308), anti-mouse CD4-FITC (GK1.5 Catalog No: 100406), anti-mouse CD8a-AF700 (53-6.7 Catalog No: 100730), anti-mouse CD19-PE (6D5 Catalog No: 115508), anti-mouse CD335-APC (29A1.4 Catalog No: 137608), anti-mouse CD4-APC/Cyanine7 (GK1.5 Catalog No: 100414), anti-mouse CD8a-Pacific Blue (53-6.7 Catalog No: 100725), and anti-mouse CD45-Pacific Blue (30-F11 Catalog No: 103126) antibodies were purchased from BioLegend. 7-AAD (Catalog No: 559925) was purchased from BioLegend. The anti-mouse CD11b-AF700 (M1/70 Catalog No: 56-0112-82), anti-mouse Ly-6G-APC (1A8 Catalog No: 17-9668-82), and anti-mouse CD11b-APC (M1/70 Catalog No: 17-0112-81) antibodies were purchased from eBioscience. The anti-Mouse Ly-6G-FITC (1A8 Catalog No: 551460) antibody was purchased from BD Pharmingen. The samples were evaluated on a CytoFLEX S Flow Cytometer (Beckman Coulter, Suzhou, Jiangsu, China), and the results were analyzed using the FlowJo software (TreeStar, version 10.0.7, Ashland, OR, USA).

\subsection{Cytokine Production Analysis}

Production of the cytokine, IFN- $\gamma$, in co-culture supernatants from the $\mathrm{T}$ cells and Ly6G ${ }^{+}$BM-MDSCs was tested using the Cytometric Bead Array Kit (BD biosciences), according to the manufacturer's instructions.

\subsection{0. $R T-q P C R$}

Total RNA was extracted using the E.Z.N.A. ${ }^{\circledR}$ Total RNA Kit I (Omega Bio-Tek, Norcross, GA, USA) and reverse transcribed using the GoScript Reverse Transcription system (Promega, Madison, WI, USA). Specific gene was amplified using $2 \times$ ChamQ Universal SYBR qPCR Master Mix (Vazyme, Nanjing, Jiangsu, China) and quantified by real-time PCR, according to manufacturer's instructions. The qPCR primers are enlisted in Supplementary Materials Table S1.

\subsection{Mouse CRPC Model and Immunotherapy}

On day -14, four- to six-week-old male FVB mice were transplanted with $3 \times 10^{6}$ Myc-CaP cells by subcutaneous injection. On day 0 , following the implantation of tumor cells, the mice were castrated by surgery. The mice were treated with $20 \mu \mathrm{g}$ human IgG, mouse IFN $\alpha 4$ (produced in house), anti-mouse PD-L1 antibody (Bioxcell, clone 10F.9G2, Lebanon, NH, USA), anti-mouse CTLA-4 antibody (produced in house), anti-mouse 4-1BB antibody (Bioxcell, clone 3H3), mouse IL-2 (produced in house), or mouse IL-9 (produced in house) on days 14, 17, and 21, by intratumoral injection. For cell depletion experiments, $200 \mu \mathrm{g}$ YTS.169.4.2 (anti-mouse CD8 antibody, produced in house), GK1.5 (anti-mouse CD4 antibody, produced in house), or PK136 (anti-mouse NK1.1 antibody, produced in house) on days 14 and 17 , by intraperitoneal injection.

\subsection{Statistical Analysis}

The data were analyzed using the GraphPad Prism 8 software (GraphPad Software Inc, La Jolla, CA, USA). The significance of assays was determined using the unpaired Student's two-tailed $t$-test. Where indicated, ${ }^{*} p<0.05,{ }^{* *} p<0.01,{ }^{* * *} p<0.001$ were considered as statistically significant results. 


\section{Results}

\subsection{G-MDSCs Are Increased in Prostate TME Following Castration}

Although androgen deprivation therapies are initially effective against prostate cancer, resistance and relapse occur eventually. During relapse, the prostate tumor cells alter their growth pattern to an androgen-independent manner. The changes in the immune cells found in the TME during the transition of prostate cancer from an androgen-dependent (AD) to a castration-resistant (CR) form remain unclear. We established a Myc-CaP prostate tumor model in immune-competent FVB mice. Following castration, we found that the Myc$\mathrm{CaP}$ prostate tumor underwent remission initially and relapsed later, which resembled the clinical development of castration-resistant prostate cancer [31]. Following the castration of the tumor-bearing mice, we analyzed the immune cell composition in the TME at different time points in both the remission and relapse periods. We found that the infiltration of $\mathrm{CD} 8^{+} \mathrm{T}$ cells, $\mathrm{CD}^{+} \mathrm{T}$ cells, and NK cells significantly decreased during the remission and relapse of prostate cancer (Figure $1 \mathrm{~A}-\mathrm{C}$ ). These results suggest the inability or weak ability of these cells to induce antitumor immunity after castration. Interestingly, a subtype of MDSCs, G-MDSCs, were significantly enriched in the TME in the relapse periods after castration (Figure 1E), but M-MDSCs decreased in the TME (Figure 1D), suggesting that G-MDSCs may be one of the primary reasons for the suppression of antitumor immunity and promotion of CRPC development.

\subsection{IFN $\alpha$ Was Effective in Controlling CRPC}

$\mathrm{T}$ cells are critical for conferring antitumor immunity. Immune checkpoint blockade antibodies targeting $\mathrm{T}$ cells have shown promising antitumor effects in both preclinical models as well as patients with cancer [32,33]. Since T cell infiltration was decreased in the TME after castration, we examined whether immune checkpoint antibodies could re-activate $\mathrm{T}$ cells to reduce the tumor burden during CRPC. For this, we combined anti-PD-L1 or anti-CTLA-4 treatment with castration. However, these two immune checkpoint antibodies showed no antitumor effects during CRPC (Figure 2A-C). Insufficient co-stimulation signal and $\mathrm{T}$ cell proliferation cytokines are possible mechanisms for weak $\mathrm{T}$ cell activation in the TME [34]. Subsequently, we combined castration with anti-4-1BB co-stimulation agonist antibody and cytokine IL-2 or IL-9. Anti-4-1BB antibodies have shown strong antitumor activity in various tumor models, including immune checkpoint blockade antibody-resistant tumor models [35-38]. The cytokine IL-2 is critical for T cell proliferation and has shown antitumor activity in both preclinical models and in patients with cancer [39]. IL-9 not only induces innate and adaptive immune responses but also directly promotes tumor apoptosis [40]. However, anti-4-1BB antibody, IL-2, and IL-9 failed to reduce tumor burden in the Myc-CaP CRPC tumor model (Figure 2D-F). Recent studies have shown that type I interferons are critical for the generation of antitumor $\mathrm{T}$ cell immunity [41]. Interestingly, IFN $\alpha 4$ treatment showed potent antitumor activity when combined with castration (Figure 2G). Since all five types (anti-PD-L1, anti-CTLA-4, anti-4-1BB, IL-9, and IL-2) of T cell-targeting treatments were not effective against CRPC, it suggests that IFN $\alpha$ treatment may generate antitumor immunity through non-T cells, such as antigen-presenting cells and immune suppressive cells, which are critical for generating antitumor immunity. 
A

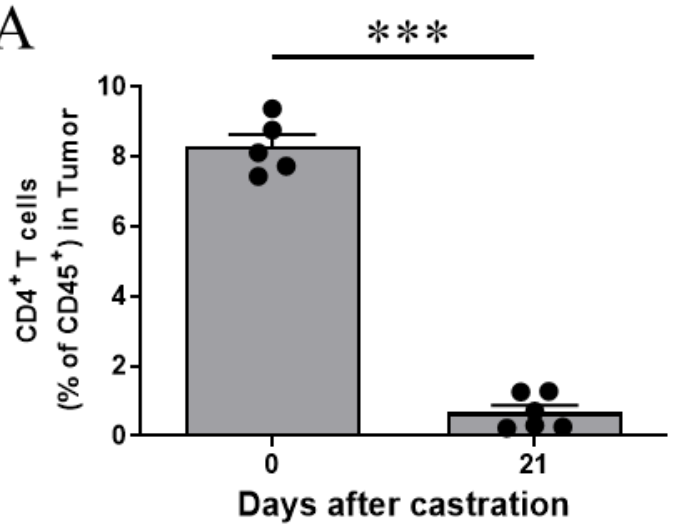

C

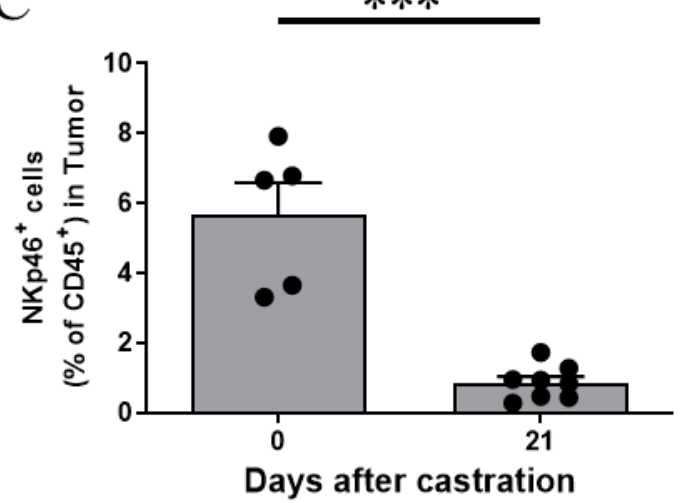

E

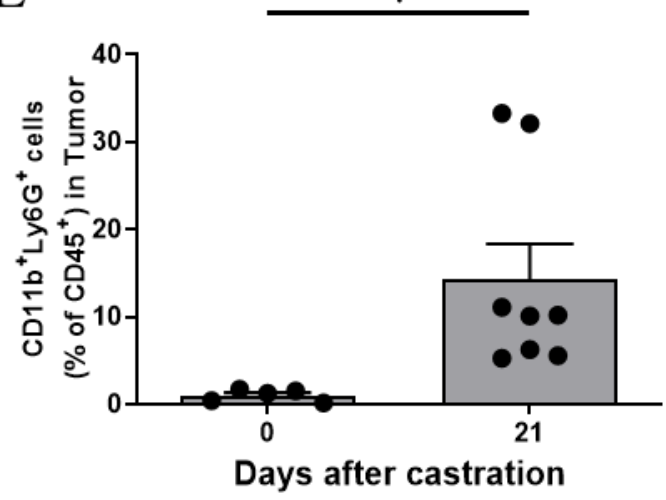

B $*$

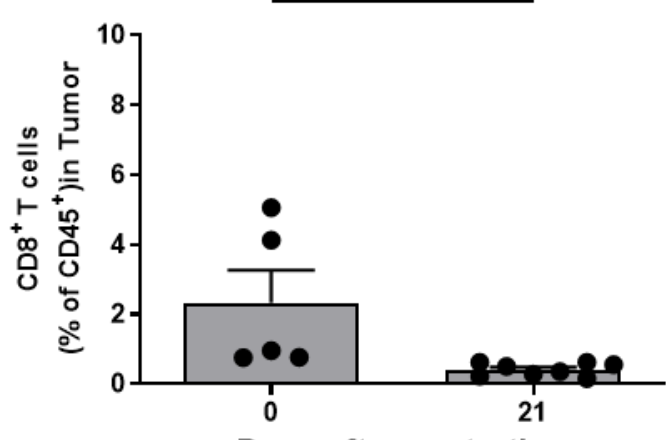

Days after castration

D

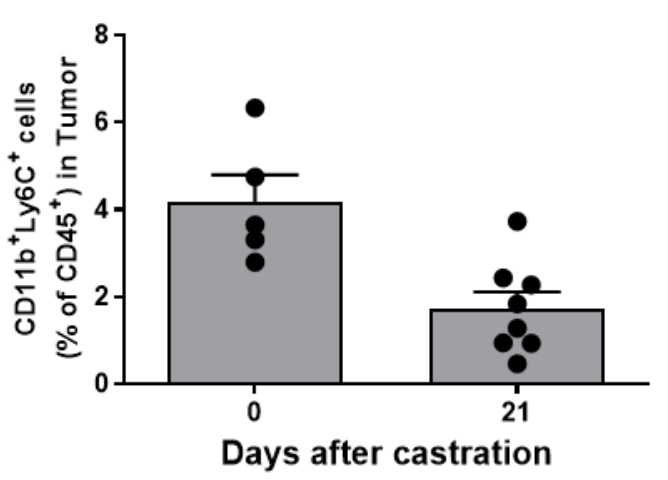

Figure 1. Analysis of the different types of immune cells in the tumor microenvironment (TME) after castration. (A-E) Male FVB mice were subcutaneously injected with $3 \times 10^{6}$ Myc-CaP cells over the right flank on day -14 and castrated by surgery on day 0 . Specific immune cells in the tumor were analyzed by flow cytometry on days 0 and 21 after castration. Representative bar graphs of the flow cytometry analyses of CD4 ${ }^{+} \mathrm{T}$ cells (A), CD8 ${ }^{+} \mathrm{T}$ cells $(\mathbf{B}), \mathrm{NK}$ cells (C), M-MDSCs (D), and G-MDSCs (E) in CD45+ immune cells in the tumor. Statistical significance was determined by unpaired $t$-test and is represented by ${ }^{*} p<0.05, * * *<0.001$. Pooled results from two replicates have been shown in (A-E) (mean \pm SEM), $n=5-8$ per group. 

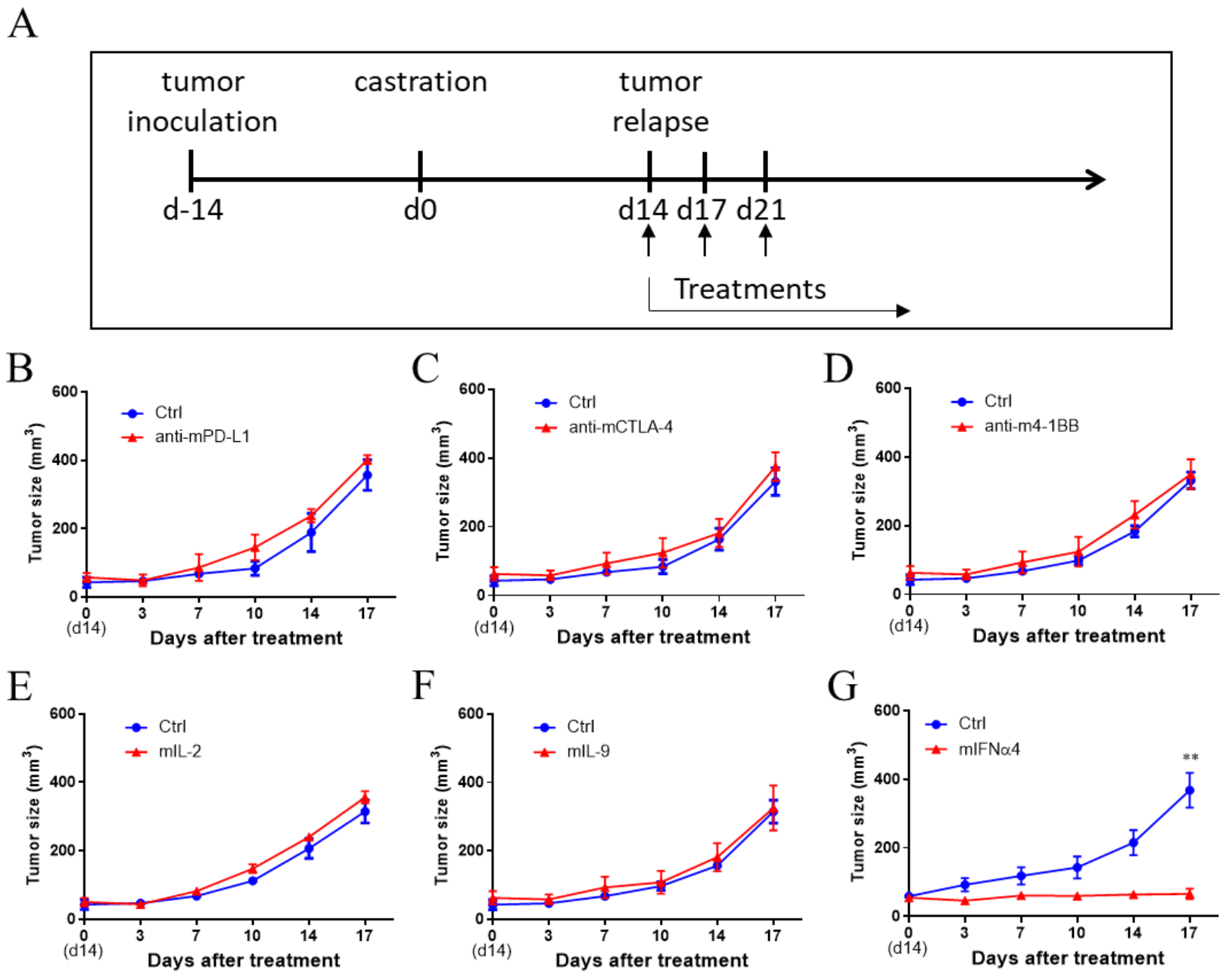

Figure 2. Therapeutic effect of different immunotherapies in CRPC mouse model. (A) Treatment schedule using different immunotherapies in Myc-CaP CRPC-bearing mice. Myc-CaP cells $\left(3 \times 10^{6}\right.$ cells/mouse) were subcutaneously inoculated over the right flank of 4-6-week-old male FVB mice. Fourteen days after inoculation, the mice were castrated by surgery. Fourteen days after castration, the tumor relapsed. The mice were administered an intratumoral injection of immune checkpoint inhibitors or cytokines ( $20 \mu \mathrm{g} /$ mouse) on days 14,17 , and 21 . The tumor volumes were measured using a vernier caliper twice a week and calculated using the formula: (length $\times$ width $\times$ height)/2. (B-G) Fourteen days after castration, the mice were treated with control (hIgG), anti-mouse-PD-L1 (B), anti-mouse-CTLA-4 (C), anti-mouse-4-1BB (D), mouse IL-2 (E), mouse IL-9 (F), or mouse IFN $\alpha 4(\mathrm{G})$. Statistical significance was determined using the unpaired $t$-test and is represented by ${ }^{* *} p<0.01$. Representative results from one of one or two replicates are shown (B-G) (mean \pm SEM), $n=4-5$ per group.

\subsection{IFN $\alpha 4$ Reduced Immunosuppression in the TME}

Since our data indicated that the $\mathrm{T}$ cell targeting treatment through immune checkpoint blockade, co-stimulation enhancement, and T cell growth stimulation was not sufficient to activate efficient antitumor $\mathrm{T}$ cell immune response, we hypothesized that non- $\mathrm{T}$ immune cells may be critical for IFN $\alpha$-mediated tumor suppression. To verify this, we analyzed the immune cell profile in the TME of castrated Myc-CaP bearing mice on day 14 post IFN $\alpha 4$ treatment. We found that the infiltration of $\mathrm{CD}_{4} 5^{+}$leukocytes in the tumor tissue was significantly increased on day $14(8.9 \%$ vs. $23 \%)$ post IFN $\alpha 4$ treatment (Figure $3 \mathrm{~A})$. Among the $\mathrm{CD}^{+} 5^{+}$leukocytes, IFN $\alpha 4$ treatment had little effect on the infiltration of $\mathrm{CD} 19^{+}$ $\mathrm{B}$ cells (Figure 3G). However, it significantly increased the infiltration of $\mathrm{CD} 4^{+} \mathrm{T}$ cells $(1.9 \%$ vs. $7.4 \%), C D 8^{+} \mathrm{T}$ cells $(0.6 \%$ vs. $9.1 \%)$, and NK cells ( $1 \%$ vs. $\left.2.5 \%\right)$ on day 14 post treatment (Figure 3B-D). These findings are consistent with the reduced tumor burden following IFN $\alpha 4$ treatment. In addition, we also observed a significant decrease in the 
proportion of immune suppressive G-MDSCs on day 14 after IFN $\alpha 4$ treatment (6.8\% vs. $1.5 \%$ ) (Figure 3F), but not M-MDSCs in the TME (2.2\% vs. 6.6\%) (Figure 3E). These data suggest that IFN $\alpha 4$ acts on multiple immune cell types to simultaneously promote cells with tumor-killing effect and reduce tumor-promoting immune suppressive cells.

A

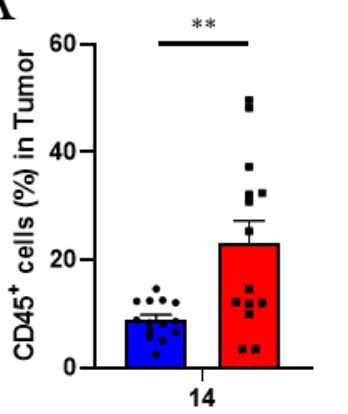

Days after treatment

D

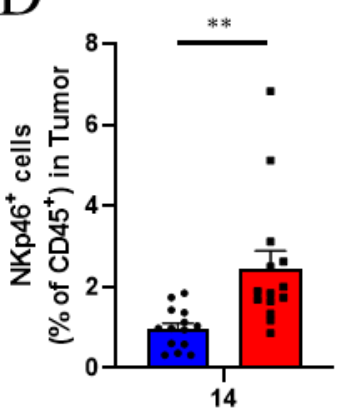

Days after treatment

$\mathrm{F}$

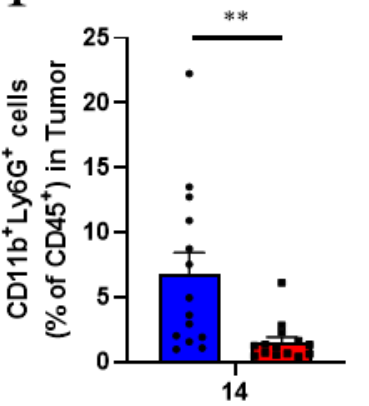

Days after treatment
$\mathrm{B}$

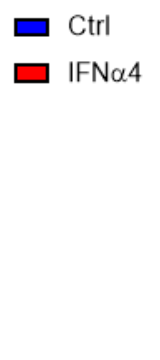

$\square \mathrm{Ctrl}$

$\square$ IFN $\alpha 4$

$\mathrm{E}$

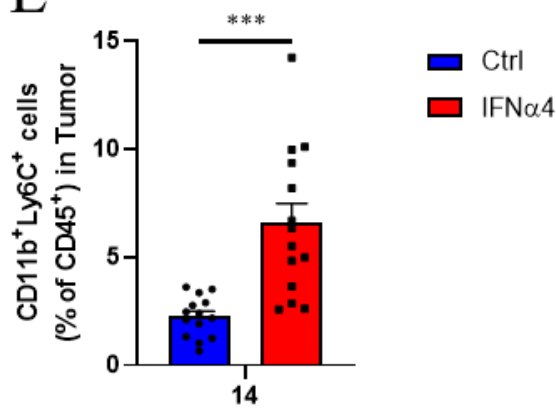

Days after treatment

G
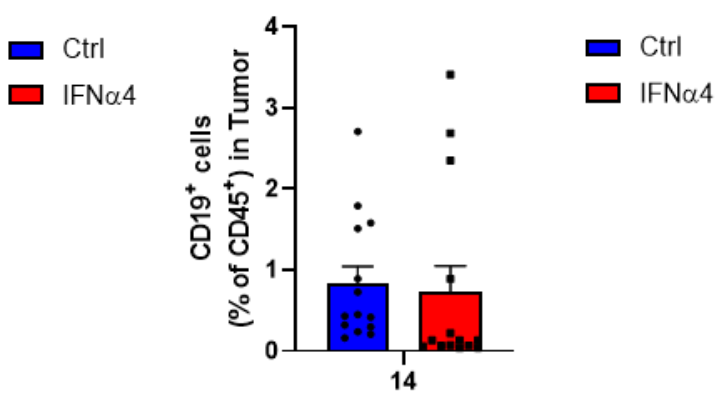

Days after treatment

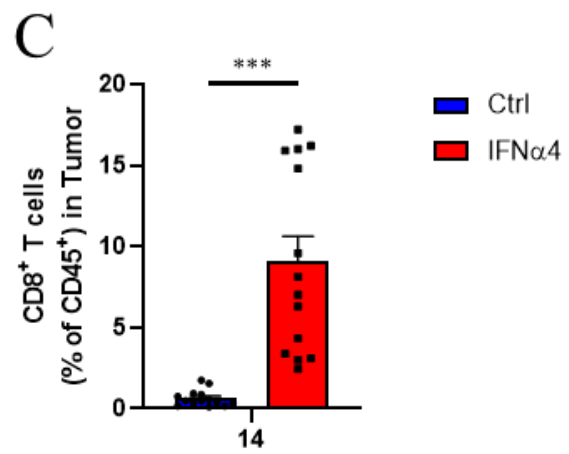

Days after treatment

Figure 3. IFN $\alpha 4$ altered the immune cell components in the TME. (A-G) Male FVB mice were subcutaneously injected with Myc-CaP cells $\left(3 \times 10^{6}\right.$ cells / mouse) on day -14 and castrated by surgery on day 0 . The mice were administered an intratumoral injection of $20 \mu \mathrm{g}$ of hIgG or IFN $\alpha 4$ on days 14,17, and 21 . The immune cells in the tumor tissue were analyzed by flow cytometry on day 14 post hIgG or IFN $\alpha 4$ treatment. Flow cytometry analysis of CD45 $5^{+}$immune cells (A), CD4 ${ }^{+} \mathrm{T}$ cells $(\mathbf{B}), C^{+}$T cells (C), NK cells (D), M-MDSCs (E), G-MDSCs (F), and B cells (G) in the tumor are shown. Statistical significance was determined using unpaired $t$-test and is represented by ${ }^{* *} p<0.01,{ }^{* * *} p<0.001$. Pooled results from four replicates have been shown in $(\mathbf{A}-\mathbf{G})$ (mean $\pm \mathrm{SEM}), n=14$ per group.

\subsection{Cytotoxic T Cells Are Critical for IFN $\alpha$-Mediated Therapeutic Effect on CRPC}

IFNAR is widely expressed on almost all cell types, including tumor and non-tumor cells, which are potential targets of IFN $\alpha$ treatment. Besides their direct inhibition of tumor growth, recent studies have highlighted the importance of IFN $\alpha$ in activating various immune cells, including T cells and NK cells [42]. In this study, first, we tested the direct effect of IFN $\alpha$ on Myc-CaP cells. Consistent with previous findings [14], IFN $\alpha 4$ significantly 
reduced Myc-CaP cell growth to about $70 \%$ in vitro (Figure $4 \mathrm{~A}$ ). Since $\mathrm{CD} 4^{+} \mathrm{T}$ cells, CD8 ${ }^{+}$ $\mathrm{T}$ cells, and NK cells are crucial antitumor components and potential targets of IFN $\alpha$, we tested if these cells were required for the IFN $\alpha$-mediated tumor suppression of CRPC. We administered $\mathrm{CD}^{+} \mathrm{T}$ cell-, $\mathrm{CD} 4^{+} \mathrm{T}$ cell-, or NK cell-depleting Ab during the IFN $\alpha 4$ treatment of castrated Myc-CaP bearing FVB mice and measured tumor growth. CD8 ${ }^{+} \mathrm{T}$ cell depletion, and not $\mathrm{CD} 4^{+} \mathrm{T}$ cell or NK cell depletion, abolished the therapeutic effect of IFN $\alpha 4$ (Figure 4B-D). These data suggest that the antitumor activity of IFN $\alpha 4$ is mediated primarily through the activation of $\mathrm{CD} 8^{+} \mathrm{T}$ cell response.

A

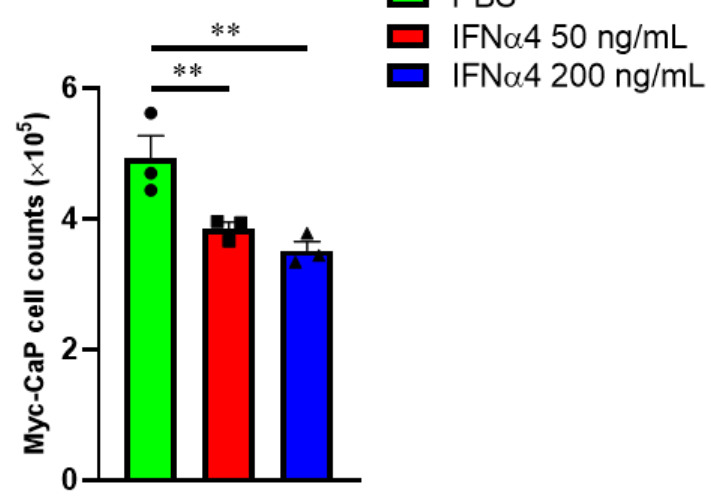

$\mathrm{C}$

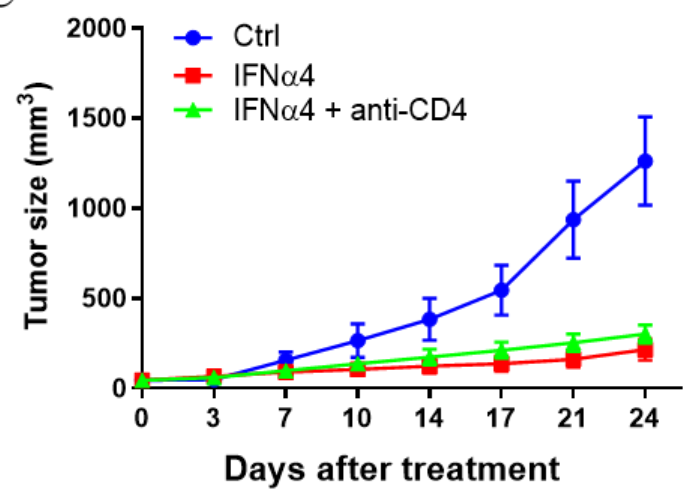

B

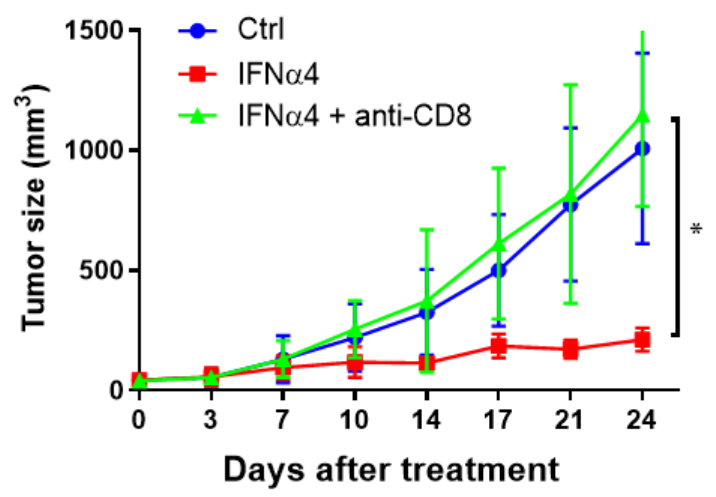

$\mathrm{D}$

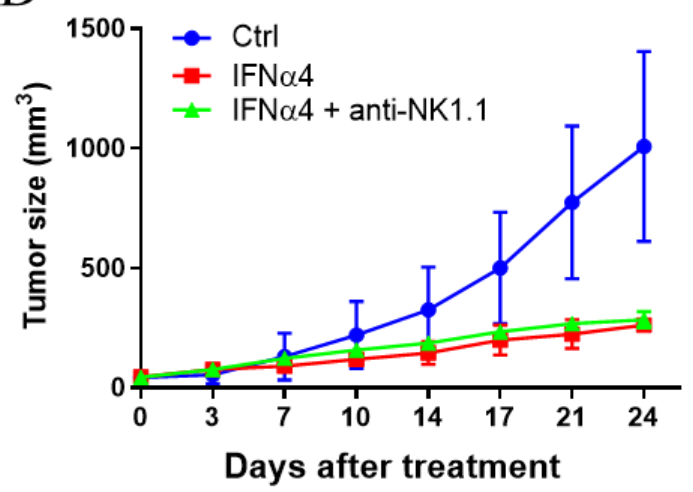

Figure 4. IFN $\alpha 4$ reduced tumor burden by directly inhibiting tumor cell growth and promoting the antitumor $\mathrm{T}$ cell response. (A) A total of $3 \times 10^{4} \mathrm{Myc}-\mathrm{CaP}$ cells were seeded in 24 well plates and treated with PBS or IFN $\alpha 4$ (50 ng/mL or $200 \mathrm{ng} / \mathrm{mL}$ ) for $48 \mathrm{~h}$. The cell count was determined and compared. Statistical significance was determined using unpaired $t$-test and is represented by ${ }^{*} p<0.01$. Representative results from one of two replicates are shown (A) (mean \pm SEM), with triplicate wells per group. (B-D) CRPC-bearing mice were treated with anti-CD8 (B), anti-CD4 (C), or anti-NK1.1 (D) Antibodies during IFN $\alpha 4$ treatment. Similar to Figure 2, mice were treated with $20 \mu \mathrm{g}$ hgG (Ctrl), $20 \mu \mathrm{g}$ IFN $\alpha 4$, or $20 \mu \mathrm{g}$ IFN $\alpha 4$ and $200 \mu \mathrm{g}$ of the aforementioned antibodies. Statistical significance was determined using unpaired $t$-test and is represented by $*<0.05$. Representative results from one of one or two replicates are shown (B-D) (mean \pm SD), $n=4-5$ per group.

\subsection{IFNa4 Inhibited the Differentiation or Proliferation of G-MDSCs}

Our results showed that IFN $\alpha 4$ reduced the accumulation of G-MDSCs and enhanced the antitumor T cell response. However, the mechanisms underlying the IFN $\alpha$-mediated reduction in the accumulation of G-MDSCs, and the contribution of this reduction to enhanced $\mathrm{T}$ cell response remained unclear. To verify this, first, we tested if IFN $\alpha 4$ affected the proliferation of G-MDSCs. We performed in vitro differentiation of G-MDSCs from bone marrow precursor cells and found that the yield of G-MDSCs was significantly reduced $\left(5.85 \times 10^{4}\right.$ vs. $\left.3.0 \times 10^{4}\right)$ when IFN $\alpha 4$ was present, suggesting that IFN $\alpha 4$ directly affects G-MDSCs differentiation and proliferation (Figure 5A). To further confirm 
this, we obtained G-MDSCs from Ifnar $1^{-/}$bone marrow cells, which lack the ability to transduce the interferon signaling pathway. We found that IFN $\alpha 4$ had no effect on Ifnar1 ${ }^{-/}$G-MDSCs differentiation and proliferation (Figure 5B). To further confirm that IFN $\alpha 4$-mediated downstream signal activation was critical for G-MDSCs differentiation and proliferation, we investigated whether IFN $\alpha 4$ possessed the same function in vivo. Three days post the second treatment of CRPC-bearing mice with IFN $\alpha 4$. We observed a decrease in the number of G-MDSCs in the bone marrow (Figure 5C). Collectively, these results demonstrate that IFN $\alpha 4$ negatively regulates G-MDSCs differentiation and proliferation both in vitro and in vivo.

A

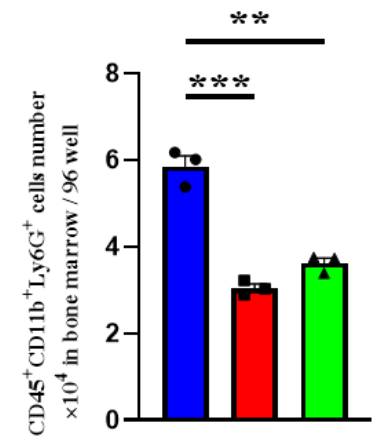

B

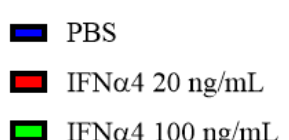

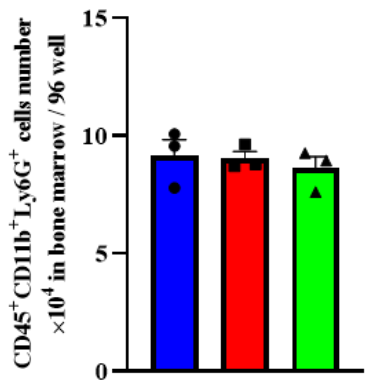

Ifnar1\%

모S
IFN $420 \mathrm{ng} / \mathrm{mL}$

口 IFNa4 $100 \mathrm{ng} / \mathrm{mL}$

C

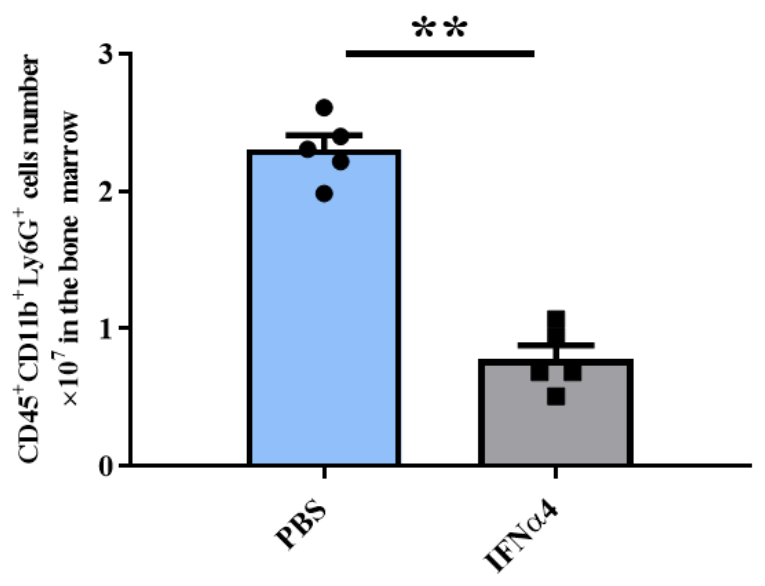

- PBS

- IFNa4

Figure 5. IFN $\alpha 4$ affected the growth of bone marrow-derived G-MDSCs. (A,B) A total of $1 \times 10^{5}$ bone marrow cells from WT mice (A) or Ifnar1 ${ }^{-/-}$mice (B) were differentiated with $20 \mathrm{ng} / \mathrm{mL}$ GM-CSF, combined with PBS or IFN $\alpha 4(20 \mathrm{ng} / \mathrm{mL}$ or $100 \mathrm{ng} / \mathrm{mL})$ for 4 days, in 96-well plates. The G-MDSCs $\left(\mathrm{CD} 45^{+} \mathrm{CD} 11 \mathrm{~b}^{+} \mathrm{Ly}_{6 \mathrm{G}}{ }^{+}\right)$cell number was compared. Statistical significance was determined using unpaired $t$-test and is represented by ${ }^{* *} p<0.01,{ }^{* * *} p<0.001$. Representative results from one of two replicates are shown $(\mathbf{A}, \mathbf{B})$ (mean \pm SEM), with triplicate wells per group. (C) Similar to Figure 2, Myc-CaP CRPC-bearing mice were treated with PBS or IFN $\alpha 4$ on days 14 and 17 after castration. On day 20, bone marrow cells were harvested, and the G-MDSCs $\left(\mathrm{CD} 45^{+} \mathrm{CD} 11 \mathrm{~b}^{+} \mathrm{Ly} 6 \mathrm{G}^{+}\right)$cell number was compared. Each point represents one mouse. Statistical significance was determined using unpaired $t$-test and is represented by ${ }^{* *} p<0.01$. Representative results from one of two replicates are shown $(\mathbf{C})$ (mean $\pm \mathrm{SEM}), n=5$ per group. 


\subsection{IFN 4 Inhibited the Immune Suppressive Function of G-MDSCs}

To test whether IFN $\alpha 4$ affected the immunosuppressive function of G-MDSCs, we performed magnetic bead sorting on in vitro differentiated G-MDSCs. An equal number of purified G-MDSCs were co-cultured with purified CFSE-labeled $\mathrm{CD}^{+} \mathrm{T}$ cells to evaluate the suppressive function of G-MDSCs on T cell activation and proliferation. We found that the inhibitory effect of G-MDSCs on both $\mathrm{CD}^{+} \mathrm{T}$ cell and $\mathrm{CD} 8^{+} \mathrm{T}$ cell proliferation was significantly reduced post exposure to IFN $\alpha 4$ (Figure 6A-D). Furthermore, to test whether IFN $\alpha 4$-treated G-MDSCs influenced the effector function of T cells, we analyzed the secretion of the T cell effector molecule, IFN- $\gamma$, in the co-culture supernatant; this revealed the activation status of $\mathrm{T}$ cells. Consistent with the reduced inhibitory effect of G-MDSCs on T cell proliferation, IFN $\alpha 4$-treated G-MDSCs showed a weaker inhibitory effect on IFN- $\gamma$ secretion from T cells following their activation (Figure 6E). In addition, we also tested the immune suppressive function of IFN $\alpha 4$-treated Ifnar1 ${ }^{-1-}$ G-MDSCs. We found that the IFN $\alpha 4$-mediated reduction in the immune suppressive function of GMDSCs was abolished in Ifnar $1^{-/-}$G-MDSCs, indicating that the activation of downstream signaling pathways is crucial for the function of IFN $\alpha$ (Figure $6 \mathrm{~F}-\mathrm{J}$ ). To elucidate the detailed regulatory mechanism of the effect of IFN $\alpha 4$ on G-MDSCs, we analyzed the mRNA expression profile of molecules associated with T cell activation by G-MDSCs cells. We observed a significant increase in the expression levels of co-stimulatory molecules such as ICOSL, TNFSF14, and CD40L, and T cell growth factors such as IL-7 and IL-15 (Figure 6K). These data suggest that IFN $\alpha 4$ not only inhibits the proliferation of G-MDSCs but also affects its immune suppressive function. 

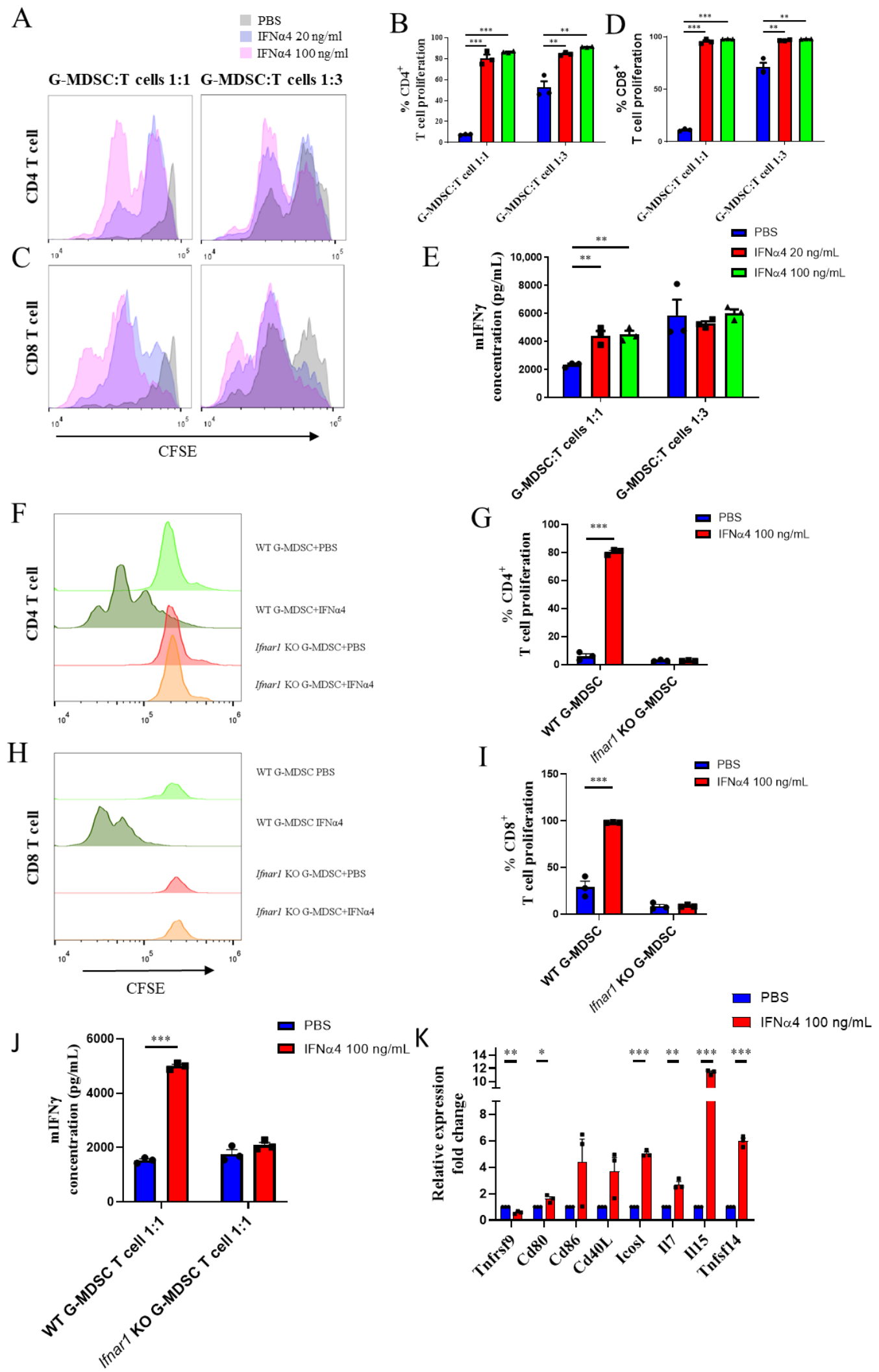

Figure 6. IFN $\alpha 4$ inhibited the suppressive function of G-MDSCs on T cell proliferation and activation. (A-E) Bone marrow cells from WT mice were differentiated with $20 \mathrm{ng} / \mathrm{mL}$ GM-CSF combined with PBS or IFN $\alpha 4$ (20 ng/mL or $100 \mathrm{ng} / \mathrm{mL})$ for 4 days, and the G-MDSCs obtained were purified using anti-Ly6G magnetic beads. A total of $1 \times 10^{5}$ CFSE-labeled, purified $\mathrm{CD}^{+} \mathrm{T}$ cells were co-cultured with purified G-MDSCs in a 1:1 and 3:1 ratio, respectively, in the presence of coated anti-CD3 and anti-CD28 antibodies. Forty-eight hours later, the proliferation of CD4 ${ }^{+} \mathrm{T}$ cells and $\mathrm{CD} 8^{+} \mathrm{T}$ cells was measured by CFSE dilution using flow cytometry (A-D). The concentration of the T cell effector cytokine, IFN- $\gamma$, in the supernatant was 
measured using the CBA kit $(\mathrm{E}) .(\mathrm{A}, \mathrm{C})$ represent the $\mathrm{CD}^{+}{ }^{+}$or $\mathrm{CD} 8^{+} \mathrm{T}$ cell CFSE dilution histogram. (B,D) represent the percentage of divided cells in total $\mathrm{CD}^{+}$or $\mathrm{CD} 8^{+} \mathrm{T}$ cells. Statistical significance was determined using unpaired $t$-test and is represented by ${ }^{* *} p<0.01,{ }^{* * *} p<0.001$. Representative results from one of two replicates are shown (A-E) (mean \pm SEM), with triplicate wells per group. (F-J) WT or Ifnar $1^{-/-}$mice-derived bone marrow cells were differentiated with $20 \mathrm{ng} / \mathrm{mL}$ GM-CSF combined with PBS or $100 \mathrm{ng} / \mathrm{mL}$ IFN $\alpha 4$ for 4 days, and the G-MDSCs obtained were purified using anti-Ly6G magnetic beads. Similar to panel (A-E), WT or Ifnar1 ${ }^{-/-}$G-MDSCs were co-cultured with CFSE-labeled, purified T cells in a 1:1 ratio. The CFSE dilution of $\mathrm{CD}^{+} \mathrm{T}$ cells and $\mathrm{CD} 8^{+} \mathrm{T}$ cells $(\mathbf{F}-\mathbf{I})$ and the release of the effector cytokine, IFN- $\gamma(\mathrm{J})$, were analyzed. Statistical significance is represented by ${ }^{* *} p<0.001$. Representative results from one of two replicates are shown (F-J) (mean \pm SEM), with triplicate wells per group. (K) WT mice-derived bone marrow cells were differentiated with $20 \mathrm{ng} / \mathrm{mL}$ GM-CSF combined with PBS or $100 \mathrm{ng} / \mathrm{mL}$ IFN $\alpha 4$ for 4 days. The G-MDSCs obtained were purified using anti-Ly6G magnetic beads and subjected to RNA isolation. The expression profile of $\mathrm{T}$ cell activation-related genes was analyzed by RT-qPCR. GAPDH was used as a housekeeping gene to normalize gene expression. Statistical significance was determined using unpaired $t$-test and is represented by ${ }^{*} p<0.05,{ }^{* *} p<0.01,{ }^{* * *} p<0.001$. Representative results from one of two replicates are shown $(\mathbf{K})$ (mean \pm SEM).

\section{Discussion}

Prostate cancer usually depicts slow growth. Detection and treatment before symptoms appear often results in limited improvement in the health and survival of patients. Clinically, surgical resection, hormonal therapy, and radiation therapy are used to treat prostate cancer. Androgen deprivation drugs, such as abiraterone or enzalutamide, cause anemia, lower bone density, and CRPC. Once patients develop CRPC, they become resistant to most therapeutic drugs, thereby limiting the treatment option to a few drugs [43]. In recent decades, immunotherapy has been increasingly used for the clinical treatment of prostate cancers. It prolongs the survival of patients and has fewer side effects. The tumor vaccine, sipuleucel-T, which targets prostatic acid phosphatase (PAP), has received U.S. FDA approval to be used in the treatment of metastatic CRPC (asymptomatic/minimally symptomatic) [44]. Moreover, several PSMA-directed CAR-T cells have undergone clinical trials for the treatment of metastatic CRPC, and the drugs have been identified as safe and feasible when used at the appropriate dosage $[45,46]$. Previous studies have shown that immune checkpoint inhibitors such as anti-PD-1 and anti-CTLA-4 slightly slow down the growth of CRPC. However, when they are combined with MDSCs depleting anti-Gr1 antibody or BEZ235 (dual PI3K and mTOR inhibitor), they significantly inhibit the growth of CRPC [47]. In addition, preclinical studies have shown that anti-IL-23 antibody inhibits the growth of CRPC and increases the efficacy of enzalutamide in the treatment of CRPC [48].

In this study, we focused on understanding the changes in the immune cell profile during CRPC development and designing potential immunotherapies for the treatment of CRPC. Various mechanisms trigger the development of CRPC: the increased sensitivity of the androgen receptor (AR) pathway or AR mutations lead to androgen-independent AR activation [49]. Besides these intrinsic changes in the tumor, our results showed that the changes in the immune cell profile of the TME might also contribute to CRPC development. We found a reduction in the infiltration of $\mathrm{CD}^{+} \mathrm{T}$ cells and NK cells and an increase in the proportion of immunosuppressive cells such as G-MDSCs, which resulted in increased immunosuppressive ability. To treat CRPC, we evaluated several immunotherapies, including immune checkpoint inhibitors such as anti-PD-L1 Ab and antiCTLA-4 Ab, agonistic antibodies of co-stimulatory molecules, such as anti-4-1BB Ab, and cytokines, such as IL-2, IL-9, and IFN $\alpha 4$. These treatments have shown potent antitumor activity in some tumor models [38,50-54]. However, we found that only IFN $\alpha 4$ reduced the tumor burden in the Myc-CaP CRPC tumor model. IFN $\alpha$ directly acts on tumor cells, blocks their cell cycle progression, and induces cell apoptosis [55,56]. It also indirectly activates immune cells, promotes their effector functions, or blocks their suppression in order to kill tumor cells. Previous studies have shown that IFN $\alpha$ increases the production and survival of $\mathrm{CD}^{+}$effector T cells [57], promotes NK cell activation and effector factor release [58], promotes B cell maturation and immunoglobulin secretion [59] and increases 
the antigen-presenting ability of DCs [60]. In this study, our data indicated that IFN $\alpha 4$ may act on other non-T cells to inhibit the growth of CRPC. We found that the proportion of GMDSCs increased during the development of CRPC and decreased significantly following IFN $\alpha 4$ treatment. Furthermore, IFN $\alpha$ reduced the proliferation of G-MDSCs both in vivo and in vitro. It also decreased the G-MDSC-mediated inhibition of T cells. It is reported that MDSC-derived IL-23 contributed to the development of castration-resistant prostate cancer [23]. It will be interesting to investigate whether IFN $\alpha$ could affect IL-23 production from MDSC. Immune checkpoint antibodies have shown weak to moderate efficacy in prostate cancer [61]. It is worth testing whether IFN $\alpha$ could be combined with immune checkpoint antibodies to enhance the antitumor efficacy.

Although our findings are promising, our study has certain limitations. First, the TME contains many types of immune cells, and IFN $\alpha$, which has a wide range of effects, may affect other immune cells as well, which we did not look at. In addition to G-MDSCs, it will be interesting to elucidate the role of IFN $\alpha$ on other immune cells in the prostate cancer TME, such as NK cells, macrophages, and B cells. Second, the systemic delivery of IFN $\alpha$ has several side effects in clinical settings. Therefore, it is critical to investigate if the targeted delivery of IFN $\alpha$ against a specific prostate cancer antigen or an IFN $\alpha$ pro-drug is more effective in reducing the side effects on non-tumor tissues.

In summary, G-MDSCs are correlated with the development of CRPC. IFN $\alpha$ effectively inhibits the growth of CRPC, reduces the number of G-MDSCs in tumor-bearing mice, and decreases the inhibitory effect of G-MDSCs on T cells in vitro. Our work revealed that G-MDSCs may be a potential therapeutic target, thereby presenting a new strategy for the treatment of CRPC.

\section{Conclusions}

G-MDSCs infiltration is crucial for designing immunotherapies against CRPC. IFN $\alpha$ promotes antitumor $\mathrm{T}$ cell response against CRPC by regulating G-MDSCs, thereby presenting a potential approach for the treatment of CRPC in clinical settings.

Supplementary Materials: The following are available online at https:/ /www.mdpi.com/article/10 .3390/cancers13215574/s1, Table S1: Primers for RT-qPCR.

Author Contributions: X.Y. designed the overall project. L.F., G.X., J.C., M.L., H.Z., F.L., X.Q., X.Z., Z.L., P.H. and X.Y. performed the experiments. L.F. and X.Y. analyzed the results and wrote the manuscript. All authors have read and agreed to the published version of the manuscript.

Funding: X.Y. was supported by The National Natural Science Foundation of China (81671643 and 81971467) and Shanghai Jiao Tong University Scientific and Technological Innovation Funds (2019QYA11).

Institutional Review Board Statement: All animal studies were approved by the Animal Care and Use Committee of Shanghai Jiao Tong University (ethic code: A2015019, approved on 25/06/2015).

Informed Consent Statement: Not applicable.

Data Availability Statement: Data sharing is not applicable to this article.

Acknowledgments: We thank Michael Karin for providing Myc-CaP mouse prostate tumor cells.

Conflicts of Interest: The authors declare that the research was conducted in the absence of any commercial or financial relationships that could be construed as a potential conflict of interest.

\section{References}

1. Culp, M.B.; Soerjomataram, I.; Efstathiou, J.A.; Bray, F.; Jemal, A. Recent Global Patterns in Prostate Cancer Incidence and Mortality Rates. Eur. Urol. 2020, 77, 38-52. [CrossRef] [PubMed]

2. Hsing, A.W.; Tsao, L.; Devesa, S.S. International trends and patterns of prostate cancer incidence and mortality. Int. J. Cancer 2000, 85, 60-67. [CrossRef]

3. Wong, M.C.S.; Goggins, W.B.; Wang, H.H.X.; Fung, F.D.H.; Leung, C.; Wong, S.Y.S.; Ng, C.F.; Sung, J.J.Y. Global Incidence and Mortality for Prostate Cancer: Analysis of Temporal Patterns and Trends in 36 Countries. Eur. Urol. 2016, 70, 862-874. [CrossRef] 
4. Nam, R.K.; Cheung, P.; Herschorn, S.; Saskin, R.K.; Su, J.D.; Klotz, L.H.; Chang, M.; Kulkarni, G.S.; Lee, Y.; Kodama, R.T.; et al. Incidence of complications other than urinary incontinence or erectile dysfunction after radical prostatectomy or radiotherapy for prostate cancer: A population-based cohort study. Lancet Oncol. 2014, 15, 223-231. [CrossRef]

5. Auchus, R.J.; Sharifi, N. Sex Hormones and Prostate Cancer. Annu. Rev. Med. 2020, 71, 33-45. [CrossRef]

6. Attard, G.; Reid, A.H.M.; A’Hern, R.; Parker, C.; Oommen, N.B.; Folkerd, E.; Messiou, C.; Molife, L.R.; Maier, G.; Thompson, E.; et al. Selective Inhibition of CYP17 With Abiraterone Acetate Is Highly Active in the Treatment of Castration-Resistant Prostate Cancer. J. Clin. Oncol. 2009, 27, 3742-3748. [CrossRef]

7. Scott, L.J. Enzalutamide: A Review in Castration-Resistant Prostate Cancer. Drugs 2018, 78, 1913-1924. [CrossRef]

8. Antonarakis, E.S.; Lu, C.; Wang, H.; Luber, B.; Nakazawa, M.; Roeser, J.C.; Chen, Y.; Mohammad, T.A.; Chen, Y.; Fedor, H.L.; et al AR-V7 and resistance to enzalutamide and abiraterone in prostate cancer. N. Engl. J. Med. 2014, 371, 1028-1038. [CrossRef]

9. Borden, E.C. Interferons alpha and beta in cancer: Therapeutic opportunities from new insights. Nat. Rev. Drug Discov. 2019, 18, 219-234. [CrossRef]

10. de Weerd, N.A.; Samarajiwa, S.A.; Hertzog, P.J. Type I interferon receptors: Biochemistry and biological functions. J. Biol. Chem. 2007, 282, 20053-20057. [CrossRef]

11. Michalska, A.; Blaszczyk, K.; Wesoly, J.; Bluyssen, H.A.R. A Positive Feedback Amplifier Circuit That Regulates Interferon (IFN)-Stimulated Gene Expression and Controls Type I and type II IFN Responses. Front. Immunol. 2018, 9, 1135. [CrossRef]

12. Mowen, K.A.; Tang, J.; Zhu, W.; Schurter, B.T.; Shuai, K.; Herschman, H.R.; David, M. Arginine methylation of STAT1 modulates IFN alpha/beta-induced transcription. Cell 2001, 104, 731-741. [CrossRef]

13. Lu, L.; Zhu, F.; Zhang, M.L.; Li, Y.G.; Drennan, A.C.; Kimpara, S.; Rumball, I.; Selzer, C.; Cameron, H.; Kellicut, A.; et al. Gene regulation and suppression of type I interferon signaling by STAT3 in diffuse large B cell lymphoma. Proc. Natl. Acad. Sci. USA 2018, 115, E498-E505. [CrossRef]

14. Hobeika, A.C.; Subramaniam, P.S.; Johnson, H.M. IFNalpha induces the expression of the cyclin-dependent kinase inhibitor p21 in human prostate cancer cells. Oncogene 1997, 14, 1165-1170. [CrossRef]

15. Hiroishi, K.; Tuting, T.; Lotze, M.T. IFN-alpha-expressing tumor cells enhance generation and promote survival of tumor-specific CTLs. J. Immunol. 2000, 164, 567-572. [CrossRef]

16. Liang, S.J.; Wei, H.M.; Sun, R.; Tian, Z.G. IFN alpha regulates NK cell cytotoxicity through STAT1 pathway. Cytokine 2003, 23, 190-199. [CrossRef]

17. Braun, D.; Caramalho, I.; Demengeot, J. IFN-alpha/beta enhances BCR-dependent B cell responses. Int. Immunol. 2002, 14, 411-419. [CrossRef] [PubMed]

18. Yang, X.; Zhang, X.; Fu, M.L.; Weichselbaum, R.R.; Gajewski, T.F.; Guo, Y.; Fu, Y.X. Targeting the tumor microenvironment with interferon-beta bridges innate and adaptive immune responses. Cancer Cell 2014, 25, 37-48. [CrossRef]

19. Sprooten, J.; Agostinis, P.; Garg, A.D. Type I interferons and dendritic cells in cancer immunotherapy. Int. Rev. Cell Mol. Biol. 2019, 348, 217-262. [CrossRef] [PubMed]

20. Yu, Y.; Huang, R.; Zong, X.; He, X.; Mo, W. INFalpha-2b inhibitory effects on CD4(+)CD25(+)FOXP3(+) regulatory T cells in the tumor microenvironment of C57BL/6 J mice with melanoma xenografts. BMC Cancer 2016, 16, 397. [CrossRef]

21. Zhang, X.H.; Sun, S.Q.; Hwang, I.K.; Tough, D.F.; Sprent, J. Potent and selective stimulation of memory-phenotype CD8(+) T cells in vivo by IL-15. Immunity 1998, 8, 591-599. [CrossRef]

22. Li, C.X.; Jiang, P.; Wei, S.H.; Xu, X.F.; Wang, J.J. Regulatory T cells in tumor microenvironment: New mechanisms, potential therapeutic strategies and future prospects. Mol. Cancer 2020, 19, 1-23. [CrossRef] [PubMed]

23. Labani-Motlagh, A.; Ashja-Mahdavi, M.; Loskog, A. The Tumor Microenvironment: A Milieu Hindering and Obstructing Antitumor Immune Responses. Front. Immunol. 2020, 11, 940. [CrossRef] [PubMed]

24. Di Mitri, D.; Toso, A.; Alimonti, A. Molecular Pathways: Targeting Tumor-Infiltrating Myeloid-Derived Suppressor Cells for Cancer Therapy. Clin. Cancer Res. 2015, 21, 3108-3112. [CrossRef]

25. Umansky, V.; Blattner, C.; Gebhardt, C.; Utikal, J. The Role of Myeloid-Derived Suppressor Cells (MDSC) in Cancer Progression. Vaccines 2016, 4, 36. [CrossRef]

26. Gabrilovich, D.I.; Nagaraj, S. Myeloid-derived suppressor cells as regulators of the immune system. Nat. Rev. Immunol. 2009, 9, 162-174. [CrossRef]

27. Pal, S.; Nandi, M.; Dey, D.; Chakraborty, B.C.; Shil, A.; Ghosh, S.; Banerjee, S.; Santra, A.; Ahammed, S.K.M.; Chowdhury, A.; et al. Myeloid-derived suppressor cells induce regulatory T cells in chronically HBV infected patients with high levels of hepatitis B surface antigen and persist after antiviral therapy. Aliment. Pharmacol. Ther. 2019, 49, 1346-1359. [CrossRef]

28. Huang, B.; Pan, P.Y.; Li, Q.S.; Sato, A.I.; Levy, D.E.; Bromberg, J.; Divino, C.M.; Chen, S.H. Gr-1(+)CD115(+) immature myeloid suppressor cells mediate the development of tumor-induced T regulatory cells and T-cell anergy in tumor-bearing host. Cancer Res. 2006, 66, 1123-1131. [CrossRef]

29. Kumar, V.; Patel, S.; Tcyganov, E.; Gabrilovich, D.I. The Nature of Myeloid-Derived Suppressor Cells in the Tumor Microenvironment. Trends Immunol. 2016, 37, 208-220. [CrossRef]

30. Ellwood-Yen, K.; Graeber, T.G.; Wongvipat, J.; Iruela-Arispe, M.L.; Zhang, J.F.; Matusik, R.; Thomas, G.V.; Sawyers, C.L. Mycdriven murine prostate cancer shares molecular features with human prostate tumors. Cancer Cell 2003, 4, 223-238. [CrossRef]

31. Pu, Y.; Xu, M.; Liang, Y.; Yang, K.; Guo, Y.; Yang, X.; Fu, Y.X. Androgen receptor antagonists compromise T cell response against prostate cancer leading to early tumor relapse. Sci. Transl. Med. 2016, 8, 333ra347. [CrossRef] [PubMed] 
32. Singh, S.; Hassan, D.; Aldawsari, H.M.; Molugulu, N.; Shukla, R.; Kesharwani, P. Immune checkpoint inhibitors: A promising anticancer therapy. Drug Discov. Today 2020, 25, 223-229. [CrossRef] [PubMed]

33. Fan, Y.Q.; Zhang, C.; Jin, S.J.; Gao, Z.H.; Cao, J.; Wang, A.Q.; Li, D.W.; Wang, Q.; Sun, X.; Bai, D.S. Progress of immune checkpoint therapy in the clinic. Oncol. Rep. 2019, 41, 3-14. [CrossRef]

34. Tang, H.D.; Qiao, J.; Fu, Y.X. Immunotherapy and tumor microenvironment. Cancer Lett. 2016, 370, 85-90. [CrossRef]

35. Chen, S.H.; Lee, L.F.; Fisher, T.S.; Jessen, B.; Elliott, M.; Evering, W.; Logronio, K.; Tu, G.H.; Tsaparikos, K.; Li, X.A.; et al. Combination of 4-1BB Agonist and PD-1 Antagonist Promotes Antitumor Effector/Memory CD8 T Cells in a Poorly Immunogenic Tumor Model. Cancer Immunol. Res. 2015, 3, 149-160. [CrossRef]

36. Qu, Q.X.; Zhu, X.Y.; Du, W.W.; Wang, H.B.; Shen, Y.; Zhu, Y.B.; Chen, C. 4-1BB Agonism Combined With PD-L1 Blockade Increases the Number of Tissue-Resident CD8+T Cells and Facilitates Tumor Abrogation. Front. Immunol. 2020, 11, 577. [CrossRef]

37. Woroniecka, K.I.; Rhodin, K.E.; Dechant, C.; Cui, X.Y.; Chongsathidkiet, P.; Wilkinson, D.; Waibl-Polania, J.; Sanchez-Perez, L.; Fecci, P.E. 4-1BB Agonism Averts TIL Exhaustion and Licenses PD-1 Blockade in Glioblastoma and Other Intracranial Cancers. Clin. Cancer Res. 2020, 26, 1349-1358. [CrossRef]

38. Qi, X.Y.; Li, F.L.; Wu, Y.; Cheng, C.; Han, P.; Wang, J.Y.; Yang, X.M. Optimization of 4-1BB antibody for cancer immunotherapy by balancing agonistic strength with Fc gamma R affinity. Nat. Commun. 2019, 10, 2141. [CrossRef]

39. Rosenberg, S.A. IL-2: The First Effective Immunotherapy for Human Cancer. J. Immunol. 2014, 192, 5451-5458. [CrossRef]

40. Zheng, N.B.; Lu, Y. Targeting the IL-9 pathway in cancer immunotherapy. Hum. Vaccines Immunother. 2020, 16, 2333-2340. [CrossRef]

41. Fuertes, M.B.; Woo, S.R.; Burnett, B.; Fu, Y.X.; Gajewski, T.F. Type I interferon response and innate immune sensing of cancer. Trends Immunol. 2013, 34, 67-73. [CrossRef]

42. Ferrantini, M.; Capone, I.; Belardelli, F. Interferon-alpha and cancer: Mechanisms of action and new perspectives of clinical use Biochimie 2007, 89, 884-893. [CrossRef]

43. Shiota, M.; Yokomizo, A.; Eto, M. Taxane Chemotherapy for Hormone-naive Prostate Cancer with its expanding Role as Breakthrough Strategy. Front. Oncol. 2016, 5, 304. [CrossRef] [PubMed]

44. Kantoff, P.W.; Higano, C.S.; Shore, N.D.; Berger, E.R.; Small, E.J.; Penson, D.F.; Redfern, C.H.; Ferrari, A.C.; Dreicer, R.; Sims, R.B.; et al. Sipuleucel-T immunotherapy for castration-resistant prostate cancer. N. Engl. J. Med. 2010, 363, 411-422. [CrossRef] [PubMed]

45. Narayan, V.; Gladney, W.; Plesa, G.; Vapiwala, N.; Carpenter, E.L.; Maude, S.L.; Lal, P.; Lacey, S.F.; Melenhorst, J.J.; Fraietta, J.; et al. A phase I clinical trial of PSMA-directed/TGF beta-insensitive CAR-T cells in metastatic castration-resistant prostate cancer. J. Clin. Oncol. 2020, 38. [CrossRef]

46. Junghans, R.P.; Ma, Q.Z.; Rathore, R.; Gomes, E.M.; Bais, A.J.; Lo, A.S.Y.; Abedi, M.; Davies, R.A.; Cabral, H.J.; Al-Homsi, A.S.; et al. Phase I Trial of Anti-PSMA Designer CAR-T Cells in Prostate Cancer: Possible Role for Interacting Interleukin 2-T Cell Pharmacodynamics as a Determinant of Clinical Response. Prostate 2016, 76, 1257-1270. [CrossRef] [PubMed]

47. Lu, X.; Horner, J.W.; Paul, E.; Shang, X.; Troncoso, P.; Deng, P.; Jiang, S.; Chang, Q.; Spring, D.J.; Sharma, P.; et al. Effective combinatorial immunotherapy for castration-resistant prostate cancer. Nature 2017, 543, 728-732. [CrossRef] [PubMed]

48. Calcinotto, A.; Spataro, C.; Zagato, E.; Di Mitri, D.; Gil, V.; Crespo, M.; De Bernardis, G.; Losa, M.; Mirenda, M.; Pasquini, E.; et al. IL-23 secreted by myeloid cells drives castration-resistant prostate cancer. Nature 2018, 559, 363-369. [CrossRef]

49. Tan, M.H.E.; Li, J.; Xu, H.E.; Melcher, K.; Yong, E.L. Androgen receptor: Structure, role in prostate cancer and drug discovery. Acta Pharmacol. Sin. 2015, 36, 3-23. [CrossRef]

50. Chen, L.P.; Han, X. Anti-PD-1/PD-L1 therapy of human cancer: Past, present, and future. J. Clin. Investig. 2015, 125, 3384-3391. [CrossRef]

51. Grosso, J.F.; Jure-Kunkel, M.N. CTLA-4 blockade in tumor models: An overview of preclinical and translational research. Cancer Immun. 2013, 13, 5. [PubMed]

52. Jiang, T.; Zhou, C.C.; Ren, S.X. Role of IL-2 in cancer immunotherapy. Oncoimmunology 2016, 5, e1163462. [CrossRef] [PubMed]

53. Lee, J.E.; Zhu, Z.W.; Bai, Q.; Brady, T.J.; Xiao, H.P.; Wakefield, M.R.; Fang, Y.J. The Role of Interleukin-9 in Cancer. Pathol. Oncol. Res. 2020, 26, 2017-2022. [CrossRef] [PubMed]

54. Zitvogel, L.; Galluzzi, L.; Kepp, O.; Smyth, M.J.; Kroemer, G. Type I interferons in anticancer immunity. Nat. Rev. Immunol. 2015, 15, 405-414. [CrossRef]

55. Caraglia, M.; Marra, M.; Pelaia, G.; Maselli, R.; Caputi, M.; Marsico, S.A.; Abbruzzese, A. Alpha-interferon and its effects on signal transduction pathways. J. Cell. Physiol. 2005, 202, 323-335. [CrossRef]

56. Maeda, S.; Wada, H.; Naito, Y.; Nagano, H.; Simmons, S.; Kagawa, Y.; Naito, A.; Kikuta, J.; Ishii, T.; Tomimaru, Y.; et al. Interferonalpha acts on the S/G2/M phases to induce apoptosis in the G1 phase of an IFNAR2-expressing hepatocellular carcinoma cell line. J. Biol. Chem. 2014, 289, 23786-23795. [CrossRef]

57. Zhang, L.; Tai, Y.T.; Ho, M.Z.G.; Qiu, L.G.; Anderson, K.C. Interferon-alpha-based immunotherapies in the treatment of B cell-derived hematologic neoplasms in today's treat-to-target era. Exp. Hematol. Oncol. 2017, 6, 20. [CrossRef]

58. Swann, J.B.; Hayakawa, Y.; Zerafa, N.; Sheehan, K.C.F.; Scott, B.; Schreiber, R.D.; Hertzog, P.; Smyth, M.J. Type I IFN contributes to NK cell homeostasis, activation, and antitumor function. J. Immunol. 2007, 178, 7540-7549. [CrossRef]

59. Jego, G.; Palucka, A.K.; Blanck, J.P.; Chalouni, C.; Pascual, V.; Banchereau, J. Plasmacytoid dendritic cells induce plasma cell differentiation through type I interferon and interleukin 6. Immunity 2003, 19, 225-234. [CrossRef] 
60. Diamond, M.S.; Kinder, M.; Matsushita, H.; Mashayekhi, M.; Dunn, G.P.; Archambault, J.M.; Lee, H.; Arthur, C.D.; White, J.M.; Kalinke, U.; et al. Type I interferon is selectively required by dendritic cells for immune rejection of tumors. J. Exp. Med. 2011, 208, 1989-2003. [CrossRef]

61. Velho, P.I.; Antonarakis, E.S. PD-1/PD-L1 pathway inhibitors in advanced prostate cancer. Expert Rev. Clin. Pharmcol. 2018, 11, 475-486. [CrossRef] [PubMed] 